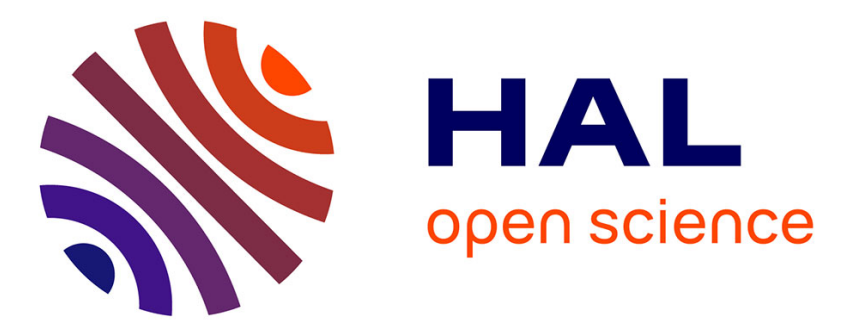

\title{
Development and optimization of a matrix converter supplying an electronic ballast - UV lamp system for water sterilization
}

\author{
Aicha Aissa Bokhtache, Abdallah Zegaoui, Michel Aillerie, Abdelkader \\ Djahbar, Kheira Hemici
}

\section{To cite this version:}

Aicha Aissa Bokhtache, Abdallah Zegaoui, Michel Aillerie, Abdelkader Djahbar, Kheira Hemici. Development and optimization of a matrix converter supplying an electronic ballast - UV lamp system for water sterilization. TMREES18-Spring Meeting "Technologies and Materials for Renewable Energy, Environment and Sustainability", Feb 2018, Beirut, Lebanon. pp.30058 - 30058, 10.1063/1.5039245 . hal-01802887

\section{HAL Id: hal-01802887 \\ https://hal-centralesupelec.archives-ouvertes.fr/hal-01802887}

Submitted on 5 Jun 2018

HAL is a multi-disciplinary open access archive for the deposit and dissemination of scientific research documents, whether they are published or not. The documents may come from teaching and research institutions in France or abroad, or from public or private research centers.
L'archive ouverte pluridisciplinaire HAL, est destinée au dépôt et à la diffusion de documents scientifiques de niveau recherche, publiés ou non, émanant des établissements d'enseignement et de recherche français ou étrangers, des laboratoires publics ou privés. 
Development and optimization of a matrix converter supplying an electronic ballast UV lamp system for water sterilization

Aicha Aissa Bokhtache, Abdallah Zegaoui, Michel Aillerie, Abdelkader Djahbar, and Kheira Hemici

Citation: AIP Conference Proceedings 1968, 030058 (2018); doi: 10.1063/1.5039245

View online: https://doi.org/10.1063/1.5039245

View Table of Contents: http://aip.scitation.org/toc/apc/1968/1

Published by the American Institute of Physics 


\title{
Development and Optimization of a Matrix Converter Supplying an Electronic Ballast - UV Lamp System for Water Sterilization
}

\author{
Aicha Aissa Bokhtache ${ }^{1,2, a)}$, Abdallah Zegaoui ${ }^{1,3,4, b)}$, Michel Aillerie ${ }^{3,4, c)}$, \\ Abdelkader Djahbar ${ }^{1}$, and Kheira Hemici ${ }^{1,2}$ \\ ${ }^{1}$ Hassiba Benbouali University, GEER Laboratory, Chlef, 02000 Algeria \\ ${ }^{2}$ Nationale Polytechnique School, Algiers, 016000, Algeria \\ ${ }^{3}$ Université de Lorraine, LMOPS-EA 4423, 57070, Metz Cedex, France \\ ${ }^{4}$ CentraleSupelec, LMOPS, $57070 \mathrm{Metz}$, France \\ a)Corresponding author: ahcial71@Gmail.com \\ b)abd.zegaoui@gmail.com, \\ c)aillerie@metz.supelec.fr
}

\begin{abstract}
Electronic ballasts dedicated to discharge lamps allow improving the quality of radiation by operating at high frequency. In the present work, the use of a single-phase direct converter with a matrix structure for supplying a lowpressure mercury-argon UVC lamp for water sterilization is proposed. The structure of the converter is based on two switching cells allowing the realization of a fully controllable bidirectional switches. The advantages of such a matrix topology include the delivered of a sinusoidal waveform current with a controllable power factor close to unity, variable in amplitude and frequency. In order to obtain the desired amplitude and frequency, a PWM control was associated in the current realization. Finally, a linear adjustment of the lamp arc current was warranted by using of a PI regulator.
\end{abstract}

Keywords. Low pressure mercury - argon discharge, UVC, Germicide effect, Electronic Ballast, PWM control, Matrix converter.

\section{INTRODUCTION}

The UVC radiation in the 200 and $280 \mathrm{~nm}$ range is produced by discharge lamps consisting of rare gas (Argon, Gallium ...) and mercury vapor. These discharge lamps, used for purification, sterilization and disinfection of liquids passed on small surfaces; have an electrical operating point, which depends on the lamp's geometry and the used gases type, but also on the electrical source powering them. It is defined by nominal voltage and current. The resulting nominal power supply involves a ballast to initiate the discharge and stabilize the discharge current.

In this current contribution, we are interested on the modeling of the supply system and the control of the electronic ballast (high-frequency current supply based on PWM inverter, delivering at its output a $0.65 \mathrm{~A}$ rms sinusoidal current at $50 \mathrm{KHz}$.) allowing optimum conditions to achieve a highly efficient discharge lamp, i.e. to generate the maximum of UV radiation at $253.7 \mathrm{~nm}$ corresponding to the most efficient germicidal wavelength.

The goal of our approach is the realization of a high efficient converter fully dedicated to electronic ballast lamp system, which is made possible thanks to the development of a relatively simple structure and control system. The chosen structure is based on a single-phase direct converter with matrix structure and a resonant circuit for the lamp.

Technologies and Materials for Renewable Energy, Environment and Sustainability AIP Conf. Proc. 1968, 030058-1-030058-10; https://doi.org/10.1063/1.5039245 Published by AIP Publishing. 978-0-7354-1675-8/\$30.00 
The control is finally assumed and optimized by a simple PI regulator introduced into the closed loop of the system in order to keep the arc current of the lamp constant yielding a luminous flux of the lamp substantially constant.

\section{THE SINGLE-PHASE MATRIX CONVERTER}

A single-phase matrix converter, SPMC, is a direct frequency converter that converts in frequency and in amplitude an AC network voltage. Due to this matrix structure of converter, a continuous intermediate circuit is not necessary. $[6-8,10]$. The SPMC consists of four bidirectional power switches placed in a matrix topology between the input voltage to the load voltage. The schematic diagram of the SPMC is shown in Figure 1. The power switches of the matrix $\mathrm{S}_{\mathrm{i}}(\mathrm{i}=1$ to 4$)$ are bidirectional allowing the transit of currents in both directions and the blocking of the voltages in two distinct polarities. [1, 10, 12].
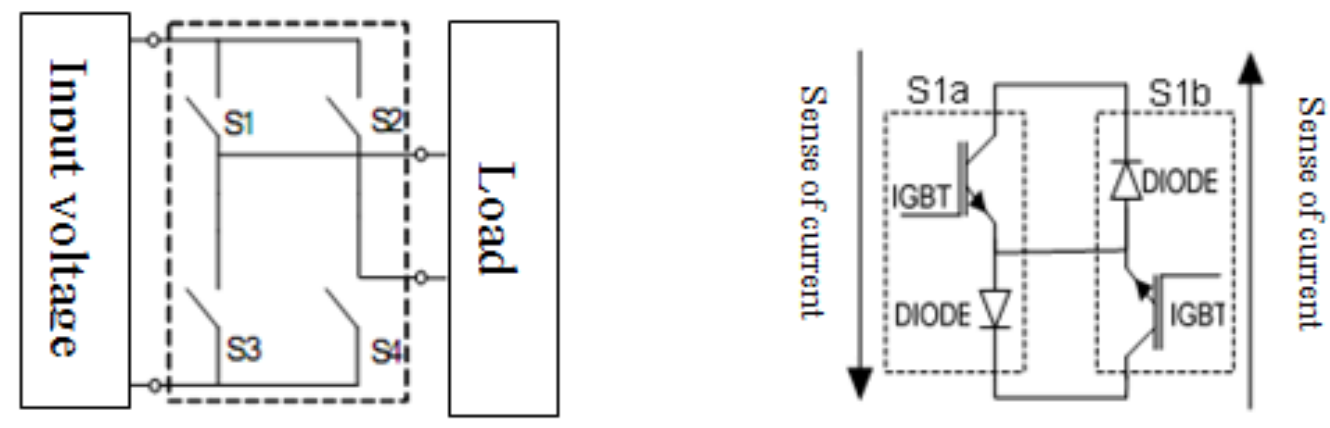

FIGURE 1.SPMC structure in the left side and the bidirectional switch in the right.

For each cell at a given moment, only one direction of the switch operates and its other direction is naturally closed. This functioning mode reduces the number of possible configurations to $2^{2}$ as shown in Figure 2.

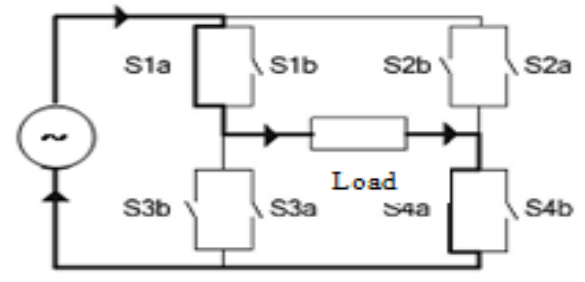

a) Step 1: positive cycle

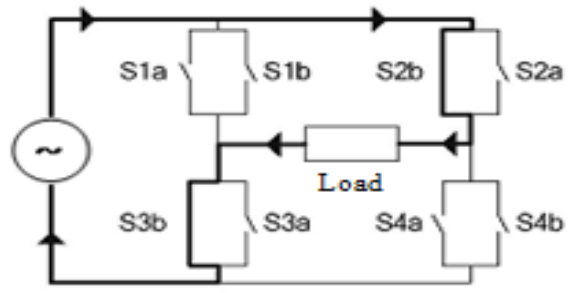

c) Step 3: positive cycle

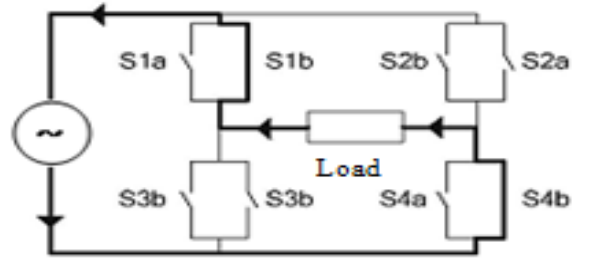

b) Step 2: negative cycle

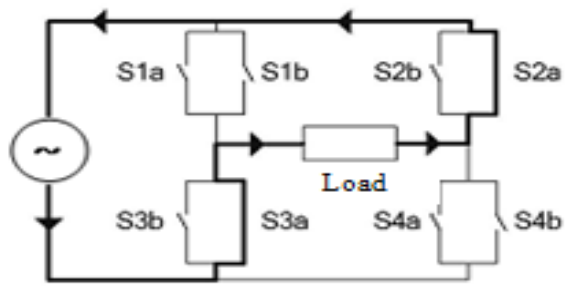

d) Step 2: negative cycle

FIGURE 2.The 4 possible operating configurations of the SPMC, [9-11].

\section{THE MATRIX - CONVERTER - ELECTRONIC DISCHARGE - BALLAST LAMP}


The association of the SPMC to the discharge lamp load is depicted in Figure 3. The electrical lamp model is selected from Ref [4]. In this schema, $L_{r}, C_{r}$ are inductance and the capacitance parameters of the resonant circuit, respectively and $i_{\text {arc }}$ and $V_{\text {arc }}$ the arc current and the arc voltage, respectively. The lamp is modeled by its filament resistor, $r_{f}$, its arc resistance, $R_{a r c}$, its starter impedance, $Z_{c p}$, represented by the starter capacitor $C_{p}$. The lamp constitutes the load that consumes $i_{r}$ (amperes) and at $V_{\text {lamp }}$ (volts). Finally, $i_{c p}$ is the starter current and $\mathrm{G}_{\mathrm{ij}}$ are the switches of the SPMC.

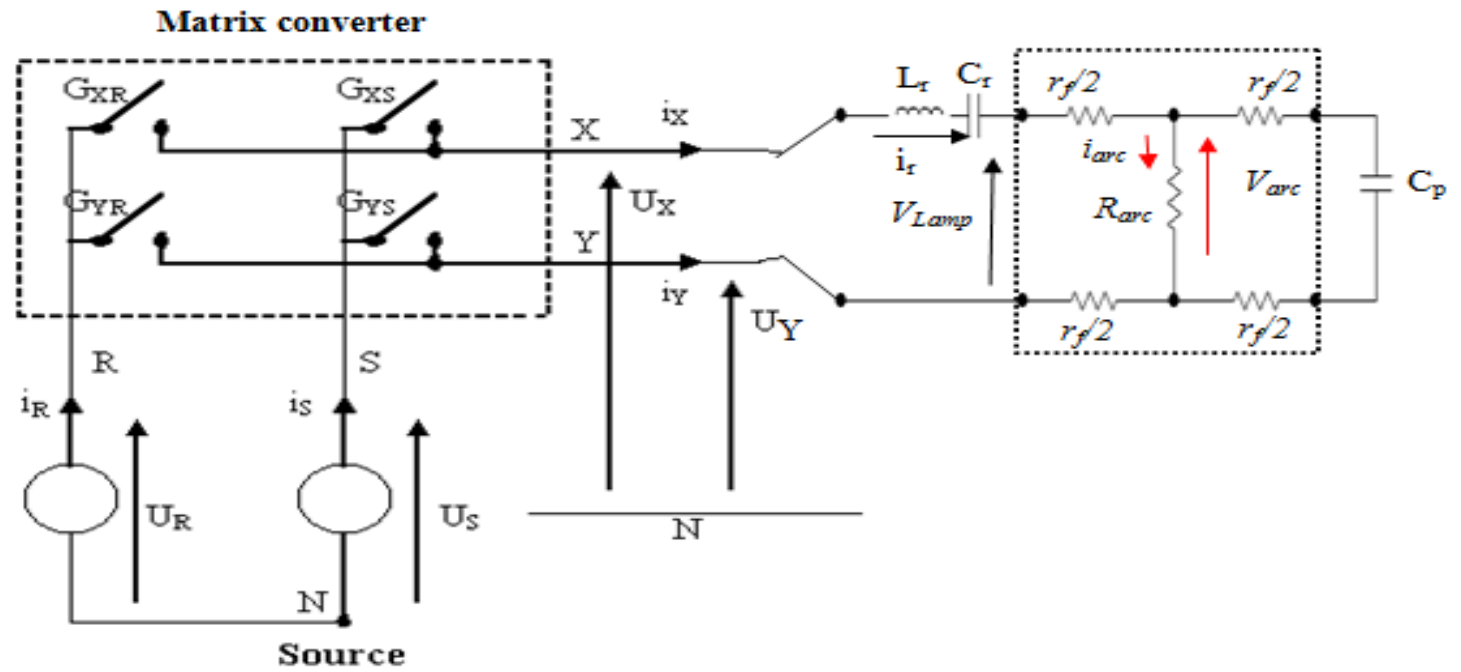

FIGURE 3.The discharge lamp-electronic ballast powered by a matrix converter [4].

We have considered in our application a lamp manufacturing by Philips ${ }^{\circledR}$, powered at $65 \mathrm{~W}$ designed for water treatment at ambient temperature with an emitted light at $253.7 \mathrm{~nm}$ [2-3]. Table 1 summarized the lamp parameters. The various parameters of the lamp, as extracted from the datasheet are summarized in Table 1.

TABLE 1. Electronic ballast circuit parameters [2-3]

\begin{tabular}{cccccccc}
\hline $\mathrm{r}_{\mathrm{f}}$ & $\mathrm{F}$ & $\mathrm{R}_{\text {arc }}$ & $\mathrm{L}_{\mathrm{F}}$ & $\mathrm{C}_{\mathrm{F}}$ & $\mathrm{L}_{\mathrm{r}}$ & $\mathrm{C}_{\mathrm{r}}$ & $\mathrm{C}_{\mathrm{p}}$ \\
\hline $5 \Omega$ & $50 \mathrm{KHz}$ & $170.769 \Omega$ & $1.5 \mathrm{mH}$ & $220 \mathrm{nF}, 630 \mathrm{~V}$ & $1.3 \mathrm{mH}$ & $10 \mathrm{nF} / 630 \mathrm{~V}$ & $4.7 \mathrm{nF} / 1600 \mathrm{~V}$ \\
\hline
\end{tabular}

The connection functions $f_{i j}$ link between the electrical switch parameters to the magnitudes imposed by the sources, such as [5-6]:

$$
\left\{\begin{array}{l}
i(t)=f_{i j}(t) \cdot i_{S}(t) \\
u(t)=\left(1-f_{i j}(t)\right) \cdot u_{S}(t)
\end{array}\right.
$$

Where $f_{i j}=1$ when the switch $\mathrm{G}_{\mathrm{ij}}$ is closed and $f_{i j}=0$ when the switch $\mathrm{G}_{\mathrm{ij}}$ is open, with $\mathrm{i}=\mathrm{X}, \mathrm{Y}$ and $\mathrm{j}=\mathrm{R}, \mathrm{S}$. (u, i) refers to electrical quantities $u_{s}$, $i_{s}$ imposed by the switched quantities.

The set of connection functions forms the matrix elements $[F]$ called the connection matrix such as:

$$
[F]=\left[\begin{array}{cc}
f_{X R} & f_{X S} \\
f_{Y R} & f_{Y S}
\end{array}\right]
$$

The modulated currents, $i_{R}$ and is of the voltage source are simultaneously connected to the state of the switching cells and so to the switched currents delivered by the current source $i_{X}$ and $i_{Y}$. Using equation 2, the conversion applied to the current source can be expressed by: 


$$
\left[\begin{array}{l}
i R \\
i \mathrm{~S}
\end{array}\right]=\left[\begin{array}{ll}
f_{X R} & f_{Y R} \\
f_{X S} & f_{Y S}
\end{array}\right] \cdot\left[\begin{array}{l}
i X \\
i Y
\end{array}\right]=\left[\begin{array}{c}
I \\
M
\end{array}\right] \cdot\left[\begin{array}{l}
i X \\
i Y
\end{array}\right]
$$

This equation high lights the "current conversion matrix" defined by $\left[{ }_{M}^{I}\right]$.

Similarly, the compound and modulated voltages $U_{X}$ and $U_{Y}$ across the current sources essentially depend on the state of the switching cells and the switched voltages $U_{R}$ and $U_{S}$ delivered by the source.

$$
\left[\begin{array}{c}
U X \\
U Y
\end{array}\right]=\left[\begin{array}{cc}
f_{X R} & f_{X S} \\
f_{Y R} & f_{Y S}
\end{array}\right] \cdot\left[\begin{array}{l}
U R \\
U S
\end{array}\right]=\left[\begin{array}{c}
U \\
M
\end{array}\right]\left[\begin{array}{c}
U R \\
U S
\end{array}\right]
$$

The obtained matrix $\left\lfloor_{M}^{U}\right\rfloor$ is called the "voltage conversion matrix".

As previously explained, the conversion matrix of the converter makes it possible to link between the modulated quantities and the switched quantities currents and voltages and, using the both above defined matrices, is expressed as follows:

$$
\left[\begin{array}{l}
U_{X} \\
U_{Y} \\
i_{R} \\
i_{S}
\end{array}\right]=[N(t)] \cdot\left[\begin{array}{c}
U_{R} \\
U_{S} \\
i_{X} \\
i_{Y}
\end{array}\right]=\left[\left[\begin{array}{c}
L_{M}^{U} \\
{[0]}
\end{array}\right]\left[\begin{array}{l}
{[0]} \\
M_{M}
\end{array}\right] \cdot\left[\begin{array}{c}
U_{R} \\
U_{S} \\
i_{X} \\
i_{Y}
\end{array}\right]=\left[\begin{array}{cccc}
f_{X R} & f_{X S} & 0 & 0 \\
f_{Y R} & f_{Y S} & 0 & 0 \\
0 & 0 & f_{X R} & f_{Y R} \\
0 & 0 & f_{X S} & f_{Y S}
\end{array}\right] \cdot\left[\begin{array}{l}
U_{R} \\
U_{S} \\
i_{X} \\
i_{Y}
\end{array}\right]\right.
$$

The calculated total impedance of the discharge lamp-electronic ballast system is given by

$Z(s)=\frac{\left(R_{a r c}+r f\right) L_{r} C_{r} C_{p} s^{3}\left[\left(2 R_{a r c}+r f\right) L_{r} C_{r} C_{p}+L_{r} C_{r}\right] s^{2}+\left(R_{a r c}+r f\right)\left(C_{r}+C_{p}\right) s+1}{\left[\left(R_{a r c}+r f\right) C_{p} s+1\right] C_{r} s}$

Where "s" is the Laplace operator.

As a result, the transfer function of the open loop system is:

$\frac{I_{\text {arc }}}{V_{l d}}=\frac{r f \cdot C_{r} \cdot C_{p} s^{2}+C_{r} s}{\left(R_{a r c}+r f\right) L_{r} \cdot C_{r} \cdot C_{p} s^{3}\left[\left(2 R_{a r c}+r f\right) L_{r} \cdot C_{r} \cdot C_{p}+L_{r} \cdot C_{r}\right] s^{2}+\left(R_{a r c}+r f\right)\left(C_{r}+C_{p}\right) s+1}$

The switches are based on MOSFET technology selected due to its efficiency in low or medium power applications (less than a few tens of kilowatts) with switching frequencies that can eventually exceed $100 \mathrm{KHz}$. In our application, the switches of SPMC are controlled by natural pulse width modulation, PWM with a modulation ratio $\mathrm{r}$ $=0.86$ and a modulation index $\mathrm{m}=21$, which makes it possible to obtain the rms current value of the desired $\left(\mathrm{I}_{\mathrm{rms}}\right.$ lamp $0.65 \mathrm{~A}$ ) at $50 \mathrm{kHz}$. Figure 4 illustrates the PWM signals strategies and the related switches control signals.

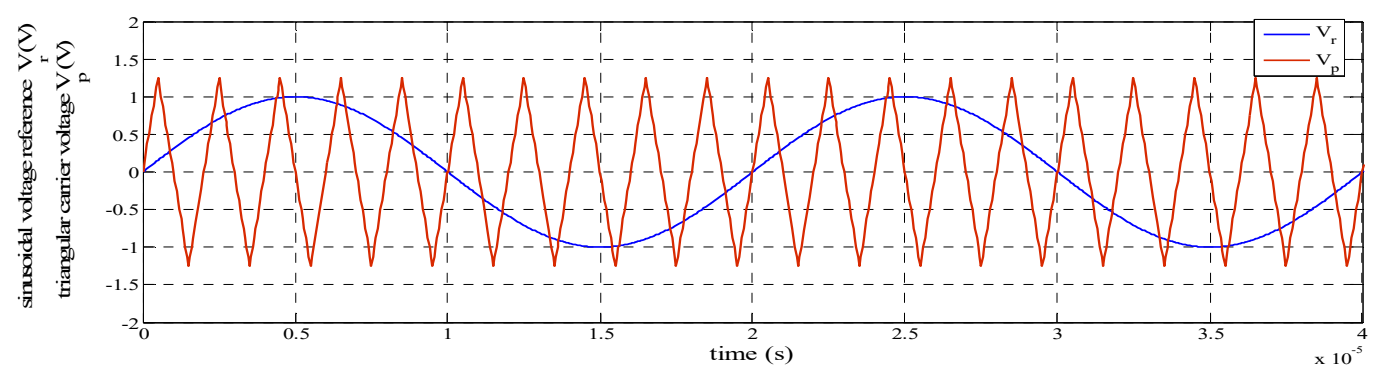



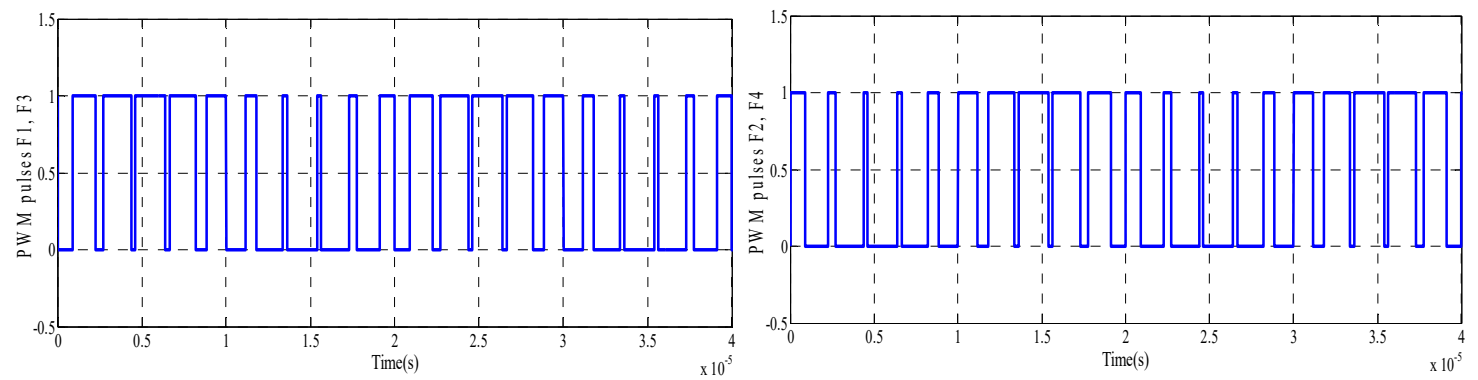

FIGURE 4.Control sequences of the switches made by the natural PWM.

\section{SIMULATION RESULTS OF THE SYSTEM IN OPEN LOOP}
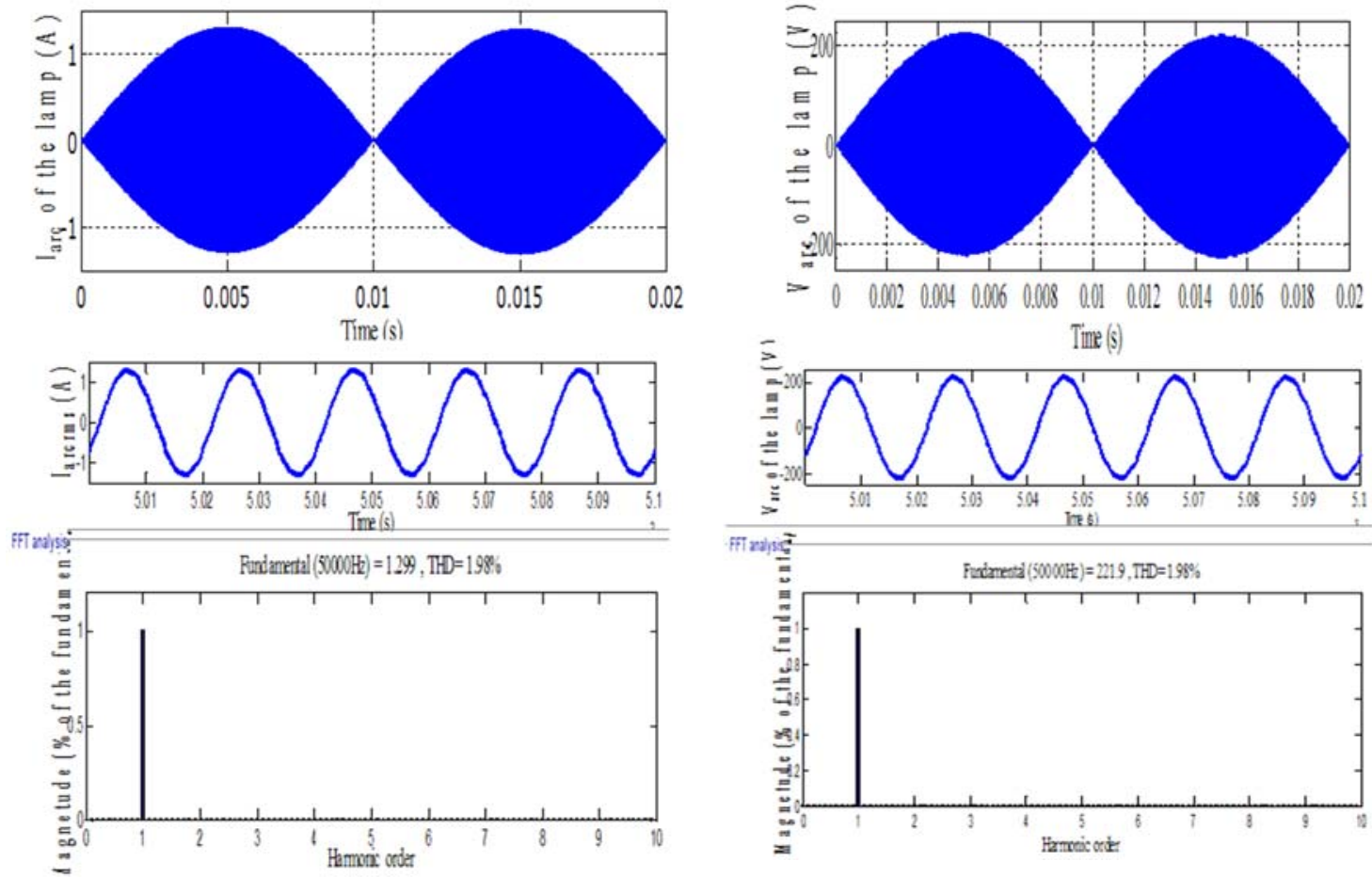

FIGURE 5. Current and arc voltage of the lamp and their harmonic spectra in open loop

Figure 5 shows the arc current, in the left side, and arc voltage, right side, waveforms across the lamp ending. Note that the envelope of the voltage and the arc current oscillate at a frequency of $100 \mathrm{~Hz}$ with the current and the arc voltage that oscillate at the desired $50 \mathrm{kHz}$ frequency. The current and the voltage are in phase (a simple resistor $R_{\text {arc }}$ characterizes the electric arc in the lamp) and the distortion rate, THD, was found equal to $1.98 \%$ for both.

Figure 6 shows both the transient and the steady state regimes of the arc current. After a transient regime with a duration of about $19.5 \mathrm{~ms}$, the effective arc current is stabilized atits desired value of $0.65 \mathrm{~A}$. 


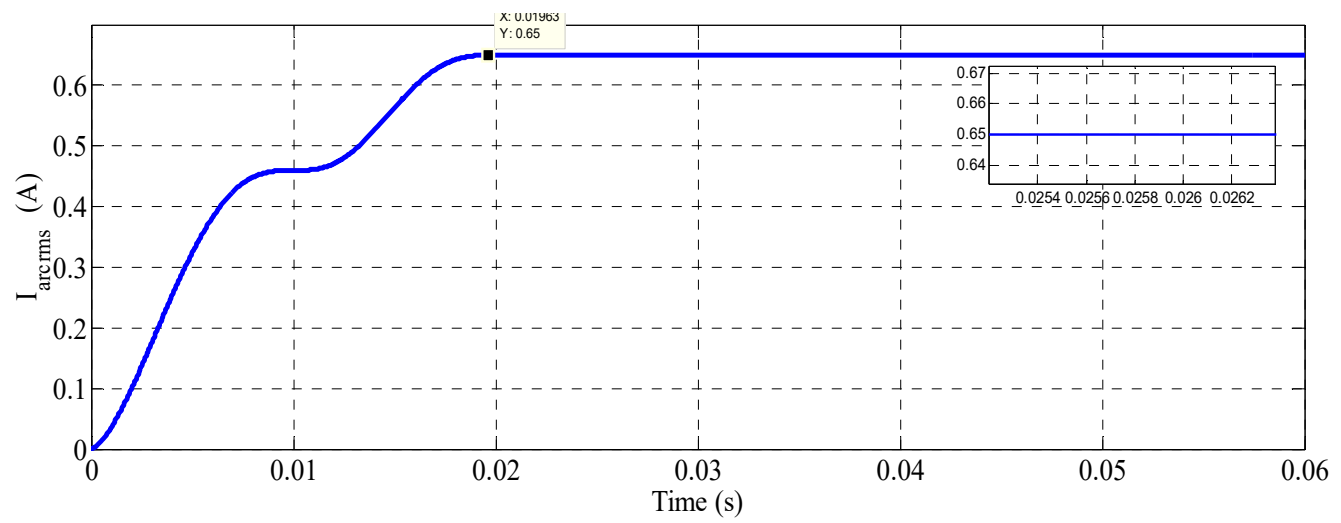

FIGURE 6.Effective arc current of the lamp in open loop

\section{SIMULATION OF THE SYSTEM IN CLOSED-LOOP}

It is obvious that a constant rms value of the arc current will improve the efficiency of the water treatment and the lifetime of the lamp. To achieve this requirement, we improve the previous system bythe consideration of a closed loop regulation with a proportional-integral regulator, PI controller, currently used in industrial systems.

The PI parameters were extracted by using of the lamp characteristics and by the resolution of the characteristic equation (8) of the transfer function in closed loop according to the pole placement method.

$$
\begin{gathered}
\left.\left[\left(R_{\text {arc }}+r_{f}\right)\right) L_{r} C_{r} C_{p}\right] s^{3}+\left[L_{r} C_{r}+\left(2 R_{\text {arc }}+r_{f}\right) r_{f} C_{r} C_{p}+r_{f} C_{r} C_{p} K_{p}\right] s^{2}+\left[\left(R_{a r c}+r_{f}\right)\left(C_{p}+C_{r}\right)+r_{f} C_{r} C_{p} K_{i}+C_{r} K_{p}\right] s \\
+C_{r} K_{i}+1=0
\end{gathered}
$$

From equation 8, we obtain the PI controller parameters as follow:

$$
\left\{\begin{array}{c}
K_{p}=\frac{\left(2 * \zeta+\omega_{n}-\left[L_{r} * C_{r}+\left(2 * R_{a r c}+r_{f}\right) * r_{f} * C_{r} * C_{p}\right.\right.}{r_{f} * C_{r} * C_{p}} \\
K_{i}=\frac{\omega_{n}{ }^{3}-1}{C_{r}}
\end{array}\right.
$$

With $\omega_{n}$, the natural frequency of the system and $K_{p}$ and $K_{i}$ are the proportional and the integral coefficients of the PI controller respectively. For a static error of $5 \%$, the response time $t_{r}$ of the system is expressed as a function of the damping $\zeta$ and $\omega_{n}$. We report in Figure 7 the current and arc voltage of the discharge lamp and their harmonics spectra in closed loop control of the system. 

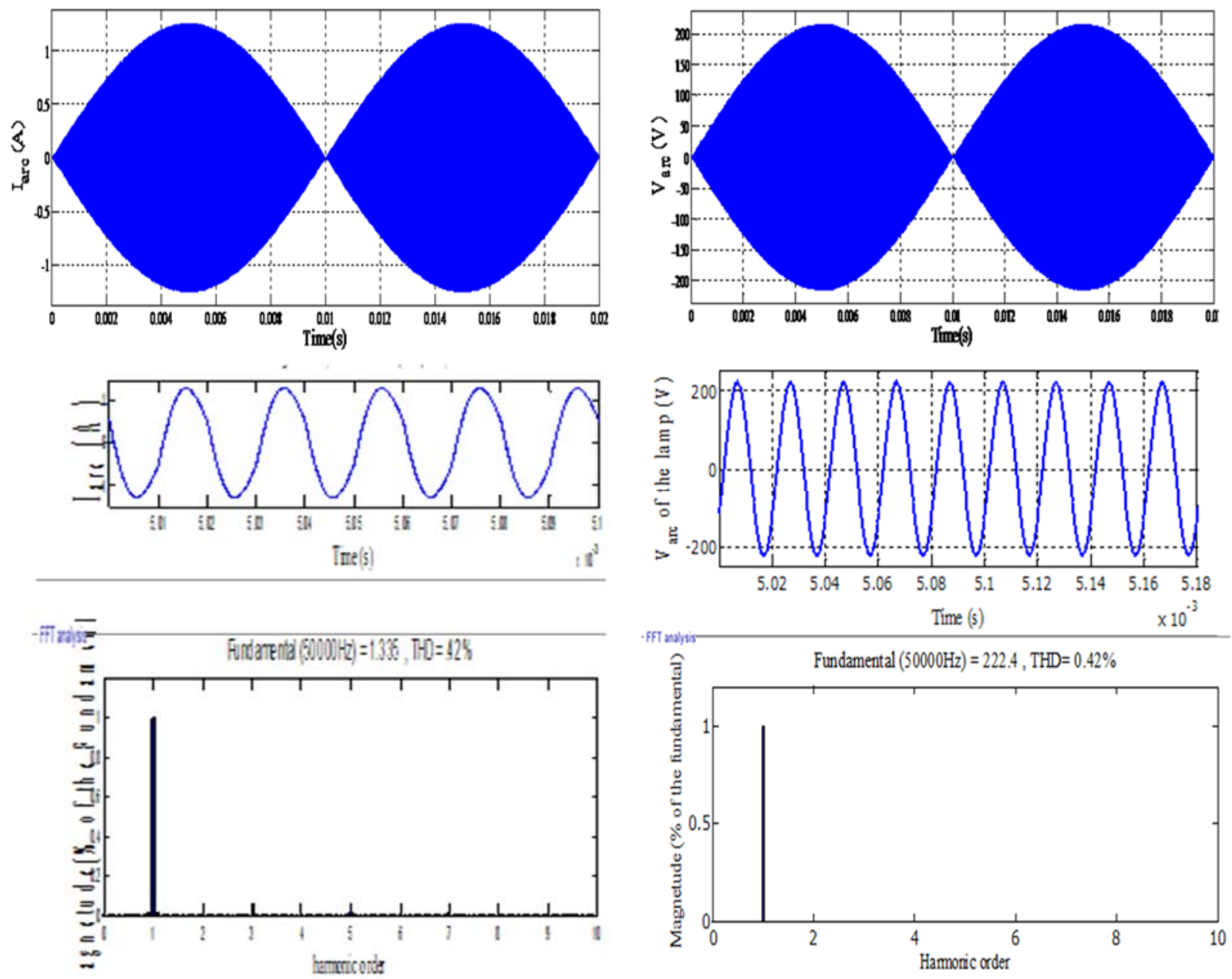

FIGURE 7.Current and arc voltage of the discharge lamp and their harmonics spectra in close loop control.

For the same reason as in the previous open-loop system, i.e. the electric arc represented by a resistor, the current and the arc voltage are fully in phase with equal THD, here at a frequency of $50 \mathrm{kHz}$. The THD was found equal to $0.42 \%$, to be compared to the value $1.98 \%$ found in the open loop control. This new value corresponds to an improve of $21 \%$ in the closed loop control using PI regulator.

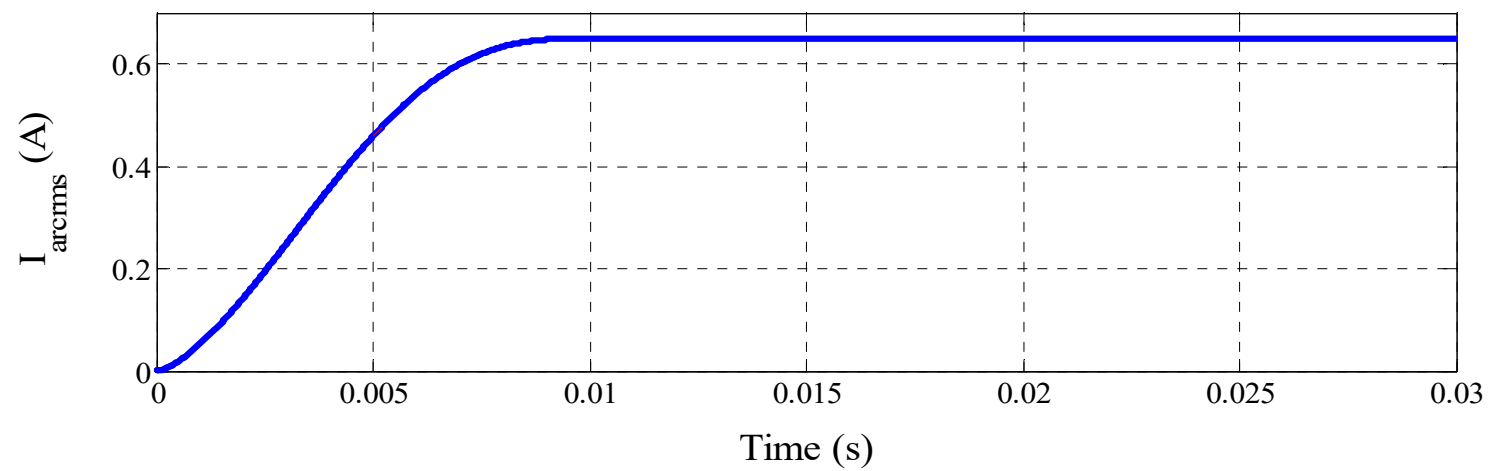

FIGURE 8.Effective arc current in close loop. 
Figure 8 shows the rms value of the arc current of the lamp. It can be seen that the rms value of the regulated arc current stabilizes at $0.65 \mathrm{~A}$. The steady state is reached after a transient regime with a huge increase during $9.5 \mathrm{~ms}$ compared to $19.5 \mathrm{~ms}$ in the open loop system. There results point out the huge increase of the efficiency of the system by using to the close loop regulation via a PI controller.

\section{TEST OF ROBUSTNESS OF THE PI REGULATOR}

To test the robustness of the PI regulator according to the temperature and arc power variations (the parameters influencing the good functioning of the system), we have disturbed the current by changes of the resistance in the computation of the gains of the corrector. A disturbance of $+50 \%$ is introduced at $12.0 \mathrm{~ms}$. Figure 9 represents the effect of the tested disturbance.
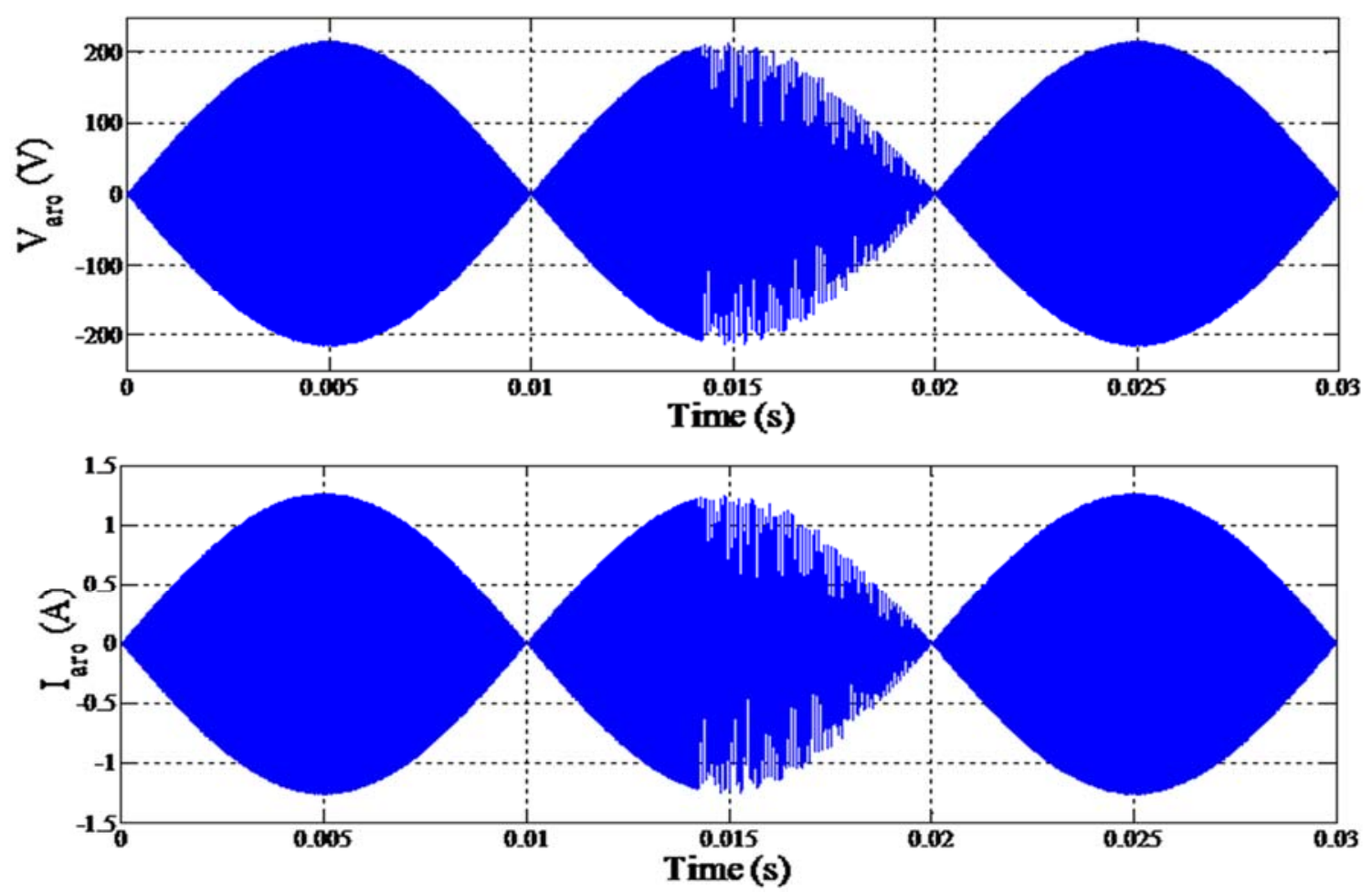

FIGURE 9. Voltage and arc current after introduction of a disturbance at $0.012 \mathrm{~s}$. 


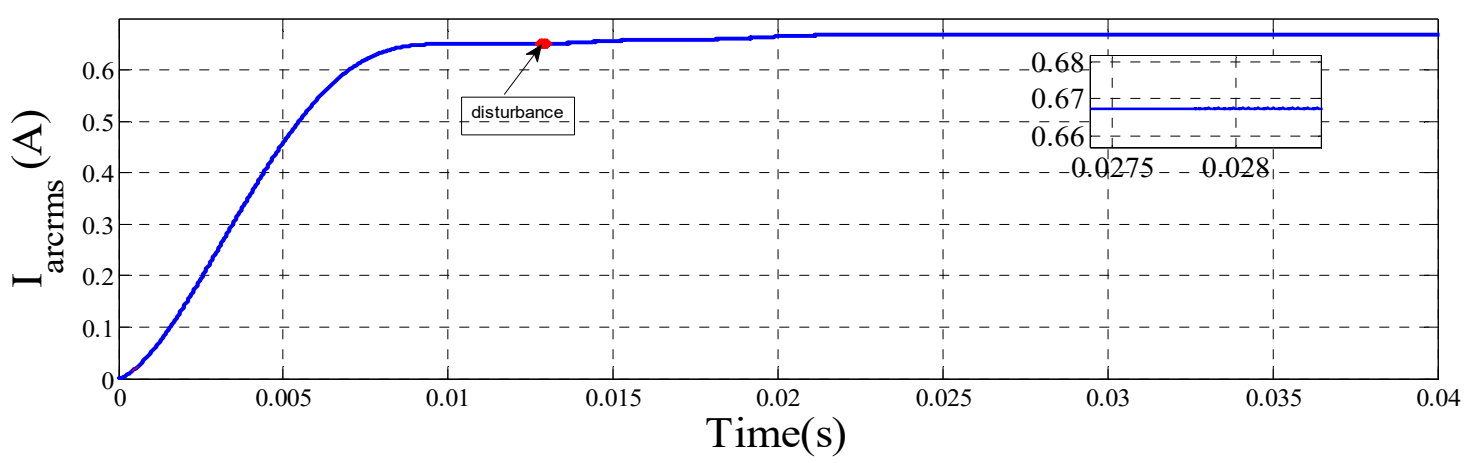

FIGURE 10.Effective arc current after introduction of a disturbance at $0.012 \mathrm{~s}$.

As it is clear in figure 9, the regulator action reject the disturbance after $8.0 \mathrm{~ms}$. The effective value of the arc current is then maintained equal to the value of $0.67 \mathrm{~A}$, slightly greater than the desired value which is $0.65 \mathrm{~A}$ as indicated in Figure 10. To correct this over value, we suggest the use of adaptive PI corrector in future works.

\section{CONCLUSION}

The present work concerns an original development of a direct matrix converter dedicated to the supply of a discharge lamp for water sterilization. The modelis based on the concepts of static converters with matrix structure of commutation switches associated to the concepts of connection, switching and conversion functions. Within a PWM control strategy, the dynamic behavior of the open-loop system for the control of the whole "matrix converterelectronic ballast-discharge lamp" is fully analyzed. The simulation results show that the arc current and voltage oscillate at the desired frequency equal to $50 \mathrm{kHz}$ with a distortion rate of $1.98 \%$ for both. The rms arc current is stabilized at $0.65 \mathrm{~A}$ corresponding to the desired value. On the second phase of optimization, the introduction of the regulator did not completely eliminate the undulations of the envelopes of the currents and voltages but allows a notorious improvement in the transient regime. Moreover, in this close-loop regulation system with introduction of a PI regulator, the THD level, here equal to $0.42 \%$ is thus significantly improved. The obtained performances obtained in this work with the matrix converter originally used for supply a discharge lamp for water sterilization, prove that this simple structure can be a good source of current to supply electronic ballast-discharge lamp in pollution harmonics plans.

\section{REFERENCES}

1. A. Abrous, "Modélisation, Commande et Réalisation d'un Convertisseur Matriciel," Thèse de Magistère, ENP (2008).

2. A. AissaBokhtache, "Contribution à la commande d'un système lampe à décharge-ballast électronique pour épuration des eaux," PhD thesis, National Polytechnic School, Algiers (2017).

3. A. Aissa-bokhtache, A. Zegaoui, M. Kellal, M.S. Boucherit, B. Belmadani, and M. Aillerie, "Optimization based on fuzzy logic control of discharge lamp-electronic ballast system for water purification," Electric Power Components and Systems, 44, 1981-1990 (2016).

4. A. Aissa-Bokhtache, A. Zegaoui, B. Belmadani, and M.S Boucherit, "Water Purification by a Lamp DischargeElectronic Ballast System Using a Full Bridge Inverter," Energy Procedia, 74, 446-452 (2015).

5. A. Bouhani Ben Ziane, “Étude et réalisation d'un convertisseur matriciel monophasé," Mémoire de Magister, Spécialité Génie Electrique, Université Hassiba Ben BOUALI de Chlef. (2012).

6. B. François, J.P. Cambronne and J-P- Hautier, "Caractérisation des convertisseurs matriciels: Structure de l'automate de commande rapprochée," J. Phys. III France 6, 625-639 (1996).

7. B. François, "Formalisme de modélisation et de synthèse des commandes appliqué aux convertisseurs statiques à structure matricielle, " $\mathrm{PhD}$ thesis, Lille University of Science and Technology (1996).

8. H. Mohd Hanafi, Z. Idris, M. K. Hamzah and Azilah Saparon, "Modelling and Simulation of Single-phase Matrix Converter as a Frequency Changer with Sinusoidal Pulse Width Modulation Using 
MATLAB/Simulink," First International Power and Energy Coference PEC on 2006 482. Putrajaya, Malaysia (2006).

9. A. Shuster, "Commande, réglage et optimisation d'un convertisseur matriciel pour entraînement par moteur asynchrone," PhD thesis, Ecole Polytechnique de Lausanne (1998).

10. M. Zahirrudin, F. Saidon, and M. Kamal Hamzah, "Implementation of Single-Phase Matrix Converter as a Direct AC-AC Converter with Commutation Strategies," IEEE PEDS (2005).

11. D. Zuckerberge, A. Weinstock, and A. Rovitz, "Single-phase matrix converter," IEE Pmc.-Electr. Power Appl., 144 (1997). 